ОСОБЛИВОСТІ РОЗВИТКУ СВІТОВОГО ГОСПОДАРСТВА ТА МЕВ

УДК 330.8

\title{
METHODOLOGICAL DISCOURSE IN ECONOMIC SCIENCE
}

\section{МЕТОДОЛОГІЧНИЙ ДИСКУРС В ЕКОНОМІЧНІЙ НАУЦІ}

\section{МЕТОДОЛОГИЧЕСКИЙ ДИСКУРС В ЭКОНОМИЧЕСКОЙ НАУКЕ}

\section{Filipenko A. S.}

Doctor of Economics, Professor, Professor of the Department of World Economy and International Economic Relations of the Institute of International Relations of Taras Shevchenko National University of Kyiv. E-mail: anton_filipenko@ukr.net

\section{Філіпенко А. С.}

Доктор економічних наук, професор, професор кафедри світового господарства і міжнародних економічних відносин Інституту міжнародних відносин Київського національного університету імені Тараса Шевченка. E-mail: anton_filipenko@ukr.net

\section{Филипенко А. С.}

Доктор экономических наук, профессор, профессор кафедры мирового хозяйства и международных экономических отношений Института международных отношений Киевского национального университета имени Тараса Шевченко. E-mail: anton_filipenko@ukr.net

Abstract. The article investigates the main approaches in the field of economic methodology. There are two methodological trends that emerged under the philosophy of science: naturalistic and constructivist. The first originates from Aristotle's materialism, the second - from Plato's ideas. Naturalized approaches eliminates distinction between the "context of discovery" and the "context of justification". Constructivism related to cognitive methodological paradigm. It means that it is more sociological in nature, concerned with connections between individuals - with learning, inter-subjectivity, and social knowledge. Thus, the main methodological views on economic theory can, on the one hand, explain the economic life in all its dimensions - the micro - macro - and geo-economic levels, establish certain patterns and trends. On the other hand, using a variety of methods - logical, mathematical, statistical, computer models and programs, new phenomena and processes of local or global nature are explored. That creates conditions for accumulation of empirical and theoretical material that enriches the economic theory, generally shaping the economic science.

Key words: economic methodology, discourse, the philosophy of science, naturalism, constructivism, realism, post-modern, methodological individualism.

Анотація. У статті розглянуті головні підходи щодо методології в економічній науці. Основна увага приділена двом методологічним поглядам у контексті філософії науки: натуралізму та конструктивізму. Натуралізм бере свої початки від матеріалізму Аристотеля, конструктивізм - від ідеалізму Платона. Натуралізм знімає відмінності між “контекстом відкриття" та "контекстом підтвердження". Конструктивізм відноситься до когнітивної методологічної парадигми. Це характеризує його соиіологічну при- 
роду, щзо проявляється у взаємозв'язках між індивідуумами, у навчанні та в соціальних знаннях. Отже, методологічні виміри економічної науки, з одного боку, пояснюють економічну реальність у всіх ї̈ проявах: на мікро-, макро- та геоекономічному рівнях. 3 іншого боку, використовуючи різноманітні методи - логічні, математичні, статистичні, комп'ютерні моделі і програми, досліджуються нові феномени і процеси локального і глобального значення. Зазначене створює передумови для узагальнення емпіричного та теоретичного матеріалу, щз поліпшує розуміння економічної теорії та економічної науки.

Ключові слова: економічна методологія, дискурс, філософія науки, натуралізм, конструктивізм, реалізм, пост-модерн, методологічний індивідуалізм.

Аннотация. $B$ статье рассмотрены ведущие методологические конщепции в современной экономической науке. Основное внимание уделено двум методологическим позициям в контексте философии науки: натурализму и конструктивизму. Натурализм берет свое начало от материализма Аристотеля, конструктивизм - от идеализма Платона. Натурализм нивелирует различия между “контекстом открытия” и “контекстом подтверждения”. Конструктивизм относится к когнитивной экономической парадигме. Это характеризует его соичологическую природу, проявляюшуюся во взаимосвязях между индивидуумами, в учебе и в сочиальных знаниях. Таким образом, методологические понятия и категории, с одной стороны, объясняют экономическую реальность во всех ее проявлениях: на микро-, макро- и геоэкономическом уровнях. С другой стороны, используя разнообразные методы - логические, математические, статистические, компьютерные модели и программы, исследуются новые феномены и процессы локального и глобального значения. Выпеизложенное создает предпосылки для обобщения эмпирического и теоретического материала, что способствует лучшему пониманию экономической теории и экономической науки.

Ключевые слова: экономическая методология, дискурс, философия науки, натурализм, конструктивизм, реализм, пост-модерн, методологический индивидуализм.

The current problem. There are two main approaches in the field of economic methodology. The overwhelming majority of scientists consider implicitly the feasibility and the absolute need of its elaboration and application in research as an important part of economics: first, to determine the subject and method of economics, its ontological and epistemological dimensions; second, to verify, test and calibrate the existing or new economic theories and models; third, to obtaining new knowledge, new theories and models; fourth, as the theoretical basis of empirical data exercising the process of economic measurement. However, there is a belief that methodology is the prerogative of philosophy of science and just a small group of economistsmethodologists. The author endorses the first position as the methodological principles, methods, tools, methodological culture, methodological standards result in the formation of a more or less homogeneous scientific economic area, give the opportunity to avoid "The Tower of Babel" effect under the diversification of economic knowledge, strengthening of interdisciplinary research under conditions of "economic imperialism".

The aim of the article is the first, to analyze the nature of economic methodology and to investigate the scope of economics as a science. This means that economic methodology examines the basic and grounds for the explanations economists give to answer why questions about the economy. For example, economists use the shifting of demand and supply curves to answer the question of why prices change. Economic methodology attempts to understand the specific role these relationships play in an explanation. Second. In article is used to both descriptive and prescriptive approaches. Descriptive economic methodology aims to describe the 
different types of economic research practices and their results. In philosophy of science descriptive methodology is often denoted as positive methodology (Latin positus which means "put" or "place"). Positive methodology concern the question of how science is actually practiced. Prescriptive economic methodology distinguishes between good and bad explanations in economics and considers how good explanations should be formulated. Prescriptive methodology in philosophy of science is denoted as normative methodology, and concern the question of how science ought to be practiced. Third. One of the most important questions in economic methodology is whether an explanation of the status and character of economics as a social science involves issues that are significantly different from those involved in explaining the status and character of the natural and character of the natural and physical sciences (M. Baumans; $J$. Davis 2010, 2-4).

\section{The important research results.}

Two worldviews. How does methodological discourse of economics look like at the beginning of XXI century? Its content and paradigm structure depends on the overall worldview or scientific outlook that provides the interpretation of any natural or social phenomena. In the years since Plato and Aristotle a discussion has been hold on the ways and methods of human perception of the world. Plato argued that ideas and their mathematical expression are primary in gaining the insight into the universe. Views of Descartes, Leibniz and others were close to the above-mentioned. Contemporary Polish philosopher Zbigniew Krol stated that "the sociologoical, economic, political, psychological and other factors are secondary. For this reason, in theory of knowledge creation, it is necessary to consider both basic and secondary levels. The basic level is determined by purely rational and ontological factors. This means that the scientific change in mathematics is a rational one and based on objective conditions prior to every scientific theory" [Z. Krol 2015, 339].

Based on mathematical priorities the model of axiomatic structure of the world and axiomatic methodology has become widespread. Patrick Suppes, a famous scholar and advocate of this method stated that "the axiomatic method has this old tradition. It was probably really first introduced in an important mathematical way by the ancient Greeks" [P. Suppes 2016, 336].

Aristotle had the opposing view, defending a metaphysical concept based on the real events and processes reflection at the level of philosophical abstractions. Bacon, Spinoza, Kant, and others also supported this approach. The philosophy of positivism followed the abovementioned school at the turn of the XIX and XX century. Nothing more than facts (bare bones) were taken into account by the followers of positivism - neo - positivists and post - positivists in the twentieth century.

Two methodological trends. In general terms the two main methodological trends emerged under the philosophy of science: naturalistic and constructivist. The first originates from Aristotle's materialism, the second - from Plato's ideas. British school of philosophy (Bacon, Locke, and Hume) formulated the naturalistic methodology basic principles further elaborated by their followers. The naturalist approach embraces the following six features. There are exist regularities or patterns in nature that are independent of the observer (that is, a Real World). These patterns can be experienced (observed), and these observations can be described objectively. Experiential statements can be tested empirically according to a falsification principles and a correspondence theory of truth. It is possible to distinguish between value-laden and factual statements. The scientific project should be aimed at the general at the expense of the particular. Human knowledge is both singular and cumulative [J. W. Moses \& T. L. Knutsen 2012, 89]. Naturalized approaches to philosophy of science eliminates distinction between the "context of discovery" and the "context of justification" in terms of Popper, Hempel and Kuhn, putting 
the actual process of discovery prior to the logic of justification and urging a thoroughgoing historical and empirical study of this process.

Constructivism methodology starts from the premise that there is an intimate and reciprocal connection between human subjects and the social world. According to Vernon Smith, "constructivism involves the use of the human mind for consciously shaping the human activity rules within the social and economic institutions" [V. Smith 2008, 427]. Constructivists see beliefs and values as something that have to be explained and as crucial in shaping and determining reality. Constructivism posits that norms and values go beyond shaping actors" interests - they in themselves constitute identities and hence interests. On the other hand, constructivism related to cognitive methodological approach. It means that it is more sociological in nature, concerned with connections between individuals - with learning, inter-subjectivity, and social knowledge. The spotlight of constructivism is on the independent effect of norms on state behavior $[B$. Cohen 2014, 18].

In a post-modern doctrine there are three constructivist logics - meaning, cognition, and uncertainty. Particularly Knightian uncertainty [F. Knight 1921] - emphasize the social construct that inform agents and the communities of which they are a part. This style of analysis makes discourse central to its narration of economics, and the position a subject takes within that discourse then defines the subject identity. For post-modern constructivists methodological norms are objects of power that determine the boundaries of possible speech and action (communication of Habermas discourse) and operate by exclusion of alternatives as much as by constitution of identities. Constructivism corresponds to Gadamer's hermeneutics, French deconstructionists, post-structuralists. In this way of approaching scholarship the context - the structure, or the discourse within which agents are situated - is decisively influential for the very "thinkability" of options.

The third methodological trend - scientific realism - is opposed to both - the naturalism and constructivism, at the same time adopting some of their principles. The wide range of literature of this approach reveals differentiation in positioning of the schools defining themselves "transcendental realists", "relational realists", "critical realists", "empirical realists". Occasionally, scientific realism, tending to the naturalism by its ontological characteristics (recognizes the existence of the real world independent of our experience), tries to represent itself as a synthesis of the two leading contemporary methodological trends - naturalism and constructivism.

Going back to the beginning of the thesis, it can be argued that in economics there is a qualitative and quantitative methodology. The first is based on the philosophy of science, philosophy of economics, the second - on mathematics, statistics, econometrics, computer models. The application of one of the methods in economic analysis is known as monomodel methodology. In our case we are dealing with bimodal methodology as it was denoted by Kurt Dopfer [K. Dopfer 2011, 329].

\section{The philosophical component of economic methodology}

Philosophy of economics is one of the important area of philosophy of science, which defines the general, universal trends and patterns of economic development in the world based on broad philosophical categories.

Five statements of the philosophy of science have a fundamental importance for economic theory.

1. Objectives. What are the objectives of science and scientific theorizing? Is science primarily practical activity aimed at identifying useful generalizations, or should it be seeking explanations and finding the truth?

2. Explanation. What is the scientific explanation? 
3. Theories. What theories, models and laws? How do they relate to each other? How are they being discovered and structured?

4. Verification, induction and demarcation. How are the scientific theories, models and laws verified and confirmed (or refuted). How do the settings and practices of scientists and representatives differ from other disciplines?

5. Do all sciences answer to these four questions identically both now and always? Is it possible to carry out research on human behaviour and institutions the same way we study nature? [D. Hausman 2008, 5].

The answers to these and similar questions are formulated from different ideological, philosophical, methodological positions.

The philosophical bases of economics were put in place in ancient times by Plato and Aristotle, and were further promoted by medieval theologians and philosophers.

The schools of Modern philosophy in UK and Continental Europe introduced the term "Philosophy of Economics". In particular, the philosophical problems of the economy were considered by John Stuart Mill in "Principles of Political Economy with some of their Applications to Social Philosophy" (1848).

In 1904-1907 Fritz Berolzheimer (1869-1920), the German writer, published his work "System der Rechts - und Wirtschaftsphilosophie". The works of Bentam, Fichte, Hegel, Foucault, Heidegger and others deeply rooted the philosophical bases of economic development [Th. Hoffmann 2009, 12-15].

When considering the philosophical bases of economy, three fundamental questions gain importance.

1. How do we define the essence or nature of economic reality? An answer to this question is provided by economic ontology or ontology of economy.

2. How do we collect information about the economic reality or, in other words, which are the reliable sources of information about it? This issue is investigated by epistemology.

3. How do we structure the acquired information on the knowledge content and its practical application? There is the outline of the subject matter of methodology [P. Keizer 2015, 22].

\section{The subject matter of Philosophy of Economics}

A broad explanation considers interpretation of the philosophy of economics as a subject that includes ontological, epistemological and methodological aspects of the economy, or that is a philosophical theory on economic reality. Other definitions of the philosophy of economics are close in meaning as well. Ontological, epistemological, methodological, axiological and logical dimensions form the bases, the core of philosophy of economics, its conceptual core, removing doubts and limitations regarding the economy as a science. Historical and economic approach focuses on the historical origins of philosophy of economics, specifically emphasizing on the primacy of economic and business ethics under the philosophical concepts from antiquity till modern age [Th. Hoffmann 2009, 15]. A term "wirtschaftsphilosophie" (economic philosophy) established by German philosophers Fichte and Hegel and British Bentham and Mill is applied in German literature. Economic philosophy means the philosophy of economic life and economic thought worldwide. It is considered as a social philosophy and acquired rational justification in Descartes' time. History and economic version considers historical resources (source) of the philosophy, economy, having in mind the natural, human and intellectual components.

One of the important components of the philosophy of economics is a philosophical verification of economic rationality. First, it is determined by the relation between utility theory and individual choice theory. Secondly, is taking into account the assumption of selfishness or selfinterest as a condition of the pure theory. Thirdly, philosophers indicate that real psychological 
actors rely on actions, far from pure theory of economic rationality. Fourth, more emphasis is put on the assumptions of the game theory. Finally, some philosophers analyze the economic rationality characteristics for real individuals by means of experiments. Economical ethics and ethical value in the economy are also vitally important in philosophy of economics [A. Sen 2009, 358-361].

Thus, philosophy of economy in the broad sense substantially includes economic ontology, epistemology and methodology of economics, rational choice decision theory, game theory, ethical economy and justice. In the narrow, pragmatic sense the Oxford Dictionary defines the philosophy of economics as an interaction of people, institutions (companies, countries) in their historical development with application in the study of game theory, linear and dynamic programming.

\section{The genesis of economic methodology}

Background of economic methodology covers the century between 1850 and $1950^{\text {th }}$. It consists of the workings by James. S. Mill, work by John. N. Keynes "The Scope and Method of Political Economy" (1891), the contribution of Mises, Knight and Robbins - adherents of the Austrian school. There are distinguished works of L. Robbins "The Nature and Significance of Economic Science" (1932) and T. Hutchison "The Significance and Basic Postulates of Economic Theory" (1938). M. Friedman's publication - "The Methodology of Positive Economics" (1953) - became to some extent a summarizing work of this period [D. Hausman 2008 31-34].

One of the key provisions of this period is Robbins' definition of the economics: "Economics is the science which studies human behavior as a relationship between ends and scarce means which have alternative uses..." [L. Robbins 2008, 75].

The next important step in shaping the approach was a normative critique of the economics during the 1970s known as the Rise of Keynesianism. As response to this criticism, provisions of the philosophy of science developed back in the 1950-60s had been applied.

The Formalist Revolution of the 1950s is considered to be a breakthrough in the history of economic methodology. A new level of mathematical science, which prospered since 1930s to 1970 s, made the formalist revolution a real revolution. Mathematical Economics is considered a science because of its incontestability.

However, there were serious reservations against the dominance of mathematics in the economy insofar that threatens to render to nullify the content of the subject of economics due to the loss of its fundamental essential features.

The philosophy of science involvement in the mid-1970s is another breakthrough in the history of economists' methodological insight. A necessary condition for the introduction of philosophical experience was diminishing role, if not distancing, of the context where a methodological reflection occurs. It turns out that economists hold implicitly expressed views now - primarily Popper's views.

Imposing of such views had becoming easier to the extent that the majority of economists kept themselves from participating in methodological discussions [T. Düppe 2011 166, 171172].

In the early 1980s economic methodology acquires the independent character. The first publication of historians and methodologists appeared in "Research in the History of Economic Thought and Methodology" journal in 1983. The "Economy and Philosophy" journal was established in 1985. The first results of the efforts for economic methodology transfer on a professional basis were obtained in the late 1980s. Henry Woo and Dan Fusfeld founded The International Network for Economic method (International Network for Economic Method, INEM). 
Establishing of the economic methodology as a separate direction in economic science occurred simultaneously with the increasing number of theories. The economist is faced with both - a variety of economic theories and methods, and theories of models, theories of causality, theories of explanation and others.

The philosophical certainty, a certain slickness of methodological framework contributed to the outlining limits of economic methodology and its consolidation around Post-Keynesian representatives, who founded the Journal of Economic Methodology (1994).

\section{The main methodological views on economic theory}

Economic methodology is the philosophy of science applied in the economy. Philosophy of science examines the nature of the assumptions, types of causality, forms of explanations used in science and so on. Accordingly, economic methodology studies the nature of assumptions (idealizations), types of causality and forms of explanations used in economics [M. Baumans and J. Davis 2010, 1]. M. Blaug identifies the methodology as "a research of concepts, theories and fundamental principles of considerations adopted in a particular science. The methodology of economics - he adds, - must be understood simply as a philosophy of science in its application to the economy" [M. Blaug 2004, 35].

The main methodological views on economic theory correspond to the three philosophy of science areas: positivism (Comte, Mill), neo - positivism (Carnap, Reichenbach) post - positivism (Popper, Lakatos).

J. St. Mill methodological principles relied on causal relationships and economic determinism. He used four methods in his research: experimental, in which scientific facts are fixed, consistent with the philosophy of positivism principles; abstract, when all is due to one reason; direct deductive (considering a lot of reasons); inverse-deductive - implies that empirically discovered historical laws are explained by human abilities.

The latter method partly resembles Bayes's conditional probability method, which is currently experiencing a real renaissance. Distinctive features of the Mill's Methodology were naturalism, descriptivism and psychologism. Interdisciplinary approach takes into account the impact of political science, sociology and ethics on the economy.

The bases of methodological views of A. Marshall, representative of late positivism, form: a synthesis of rationalism with empiricism, typical for the British school of philosophy; gradualist approach, according to which the opposing sides can be combined through a gradual stepby-step process; identifying the specific economic events that have monetary measurement.

At the neo - positivism stage J. M. Keynes used to concisely express his own methodological position. In a letter to R. Harrod he pointed that, firstly, economic theory - is a branch of logic, way of thinking; secondly, advance in economic theory almost entirely is the gradual improvement of our choice; third, statistical studies are needed for both the forecast and verification of model relevance and validity; fourth, the purpose of the model is to separate acting relatively long or relatively unchanged factors from fleeting or changing ones to develop logical thinking and understand the processes that generate these factors in specific cases [economia.univ.it/harrod/edition/editionstuff/rfh.346.htm].

M. Friedman is considered an outstanding representative of post positivism in economic science. His methodological credo was formulated in the "The Methodology of Positive Economics". Analysis begins with the reference to the work of John N. Keynes "The Scope and Method of Political Economy", emphasizing that positive economics is called the "what is", and normative is referred to as the "what should be" economics.

The theory, according to Friedman, is composed of two elements - the "language" (logic and mathematics), which describes the systematic and organizational methods of argumentation and 
explanation; meaningful hypotheses, revealing the abstract essential features of complex reality. Friedman describes the logics and mathematics as a tautology; Popper defines them as theoretical sciences that do not require verification or falsification. Thus, hypothesis ought to be verified to identify their compliance with economic realities. Verification consists of two interconnected stages: justification of the hypothesis concept and testing its effectiveness and accuracy.

Friedman attaches a great importance to the assumptions, which perform three essential functions:

- describing and presenting a theory;

- facilitate an indirect test of the hypothesis by its implications;

- determination of the specific conditions under which the theory can be effective $[M$. Friedman 1953, 23].

Ultimately, the four principles of post positivism have been reflected in M. Friedman's methodology. First, it is referred to the theoretical principles of relativity, in which the facts are always theoretical characteristics. Second, the falsification principle means, on the one hand, that the conclusions of the theory are always verified by the facts, and that facts cannot prove the theory, but can only reveal its inaccuracy, on the other (Duhem-Quine thesis). Thirdly, Popper's growth of scientific knowledge is applied. Fourth, the determining principle of theory comparable strength is applied in the context that the more efficient is the theory, which conclusions are more precise and the scope of action is the most extensive. Friedman's methodology is called methodological instrumentalism, which is a form of positivism or conventionalism [J. Mulberg 1995, 15]. F. Machlup's concept known as a limited methodological instrumentalism was also close. This approach is based on the use of set of instruments which are not confirmed by the theory (assumptions, hypotheses, forecasts, etc.) or that is a methodological approach according to which all scientific theories and hypotheses are tools for developing the forecasts. However, some authors believe that methodological instrumentalism is more efficient (more suitable) on short periods for solving practical problems.

Economic methodology by J. Dewey is called pragmatic instrumentalism. Its components are fallibilism, context-sensitivity, anti-teleology. This methodology provides an opportunity of a broad social engineering and economic planning. The link between economic pragmatism and methodology can be observed in three directions. First, essentially pragmatism considerably combines (binds) scientific rationality and economic rationality. Second, pragmatic way of thinking belongs to the moral and social sciences, including the economics, while, many aspects of economic life are developing on the base of instrumental scientific rationality. Third, experimental rationality, experimental forms of life as the key concepts of pragmatism, tend to increase from antiquity to the industrial revolution, taking shape in relationships of "the industrial revolution - economic progress", "industrial rationality - scientific rationality" [D. Wade Hands 2004, 261-265].

R. Solow and O. Williamson formulated the practical aspect of pragmatic methodology. Solow's methodology took the form of three commandments: keep it simple, get it right, make it plausible.

Keep it simple: (Occam's razor) principle is accomplished by stripping away inessentials and by concentration on the effects of the first order - the most important, following which can be presented evaluations, clarifications and continuation.

"Get it right" principle entails working out the logic, and «make it plausible» principle means to preserve contact with the phenomena and eschew fanciful constructions. O. Williamson added the fourth commandment: derive refutable implications to which the relevant (often microanalytic) data are brought to bear [O. Williamson 2009 145-146]. 
Methodological individualism should be highlighted among the modern methodological concepts of economic theory, in opposite to it are methodological holism, institutional individualism, methodological institutionalism.

Methodological individualism means the explanation of social phenomena in terms of individual behaviour. The principles of methodological individualism are realized mainly in neoclassical economics (mainstream) in relation with its basic postulates:

- a model of rational economic agent that has stable preferences;

- the maximization principle, which determines the economic behaviour of market agents in accordance with the concept of subjective expected utility;

- the presence of competition between market agents;

- the possibility to achieve the market equilibrium.

According to methodological individualism in terms of individual actions, the economic events should be explained both at micro and macro level. It refers to inflation, unemployment and other macroeconomic indicators and processes. Due to the fact that the latter requires a holistic, systemic approach, methodological holism principles are more effective for their analysis. P. Keizer describes this approach as methodological collectivism [P. Keizer 2015, 24].

The principles of holism were first applied in institutional thought in the first half of the twentieth century. Thus, the main attention focused on integrated objects (groups, associations, corporations, government, supranational unions etc.). Consequently, the first approach (methodological individualism) prefers an analysis of individual actions, the second (holism) - a variety of institutions. The dispute between the two approaches caused the rise of the third trend in economic methodology - institutional individualism. A distinctive feature of this method reside in the fact, that individuals do not act arbitrarily as in the case of methodological individualism, and their behaviour is determined by institutions.

The main characteristic of the institutional individualism is the explanation of human behaviour not by the means of rationality, as assumed in the neoclassical doctrine, but on the rules and regulations (prescriptions). There are three effectiveness preconditions of this economic methodology approach. First, only actors, not institutions, can care about their interests and goals. Second, formal and informal set of institutional rules, which affect the interaction between actors, ranks among the explicable variables. Third, significant institutional changes are always the result of independent and collective actions of certain subjects and are always carried out in a broad institutional framework.

\section{Another institutional approach is called methodological institutionalism}

Its basic postulates are as follows:

- The rejection of social neutrality allegations of scientific knowledge subjects and recognition of their deep involvement in the system of professional division of labour, internal scientific connections and relationships, status interests, informal hierarchies and networks.

- Understanding of specific scientific approaches as specific institutions, that are embodied in the target groups and related agents, in their mutual trust and reputation capital, research strategies and conventions, the impact on ideology and public policy.

- Focus on the system of interaction between cognitive conflict and status interests of scientific fields' agents [D. Frolov 2008, 90-91]. These preconditions narrowly interpret the essence of methodological institutionalism.

In summary, the methodological institutionalism has holistic roots and involves the study of economic systems as integral structural units which are based on formal and informal rules (institutional individualism) and the explanation of economic phenomena in terms of operations and changes in institutional structures, including the scientific community. Examples of method- 
ological institutionalism are found in the works of Karl Polanyi, where he goes beyond the traditional methodological attitude, considering the interaction of economic and non-economic institutions. Specifically, the three types of relationships - reciprocity, redistribution and exchange - are the basis of modern research methodology of social and solidarity economy [Polanyi 2002, 59-67].

\section{The mathematical apparatus of economic methodology}

The history of economic science and economic methodology particularly indicates, that elements of mathematics have always been present in economic research. Enough to mention The economic table by Francois Quesnay (1758), "Mathematical Principles of the Theory of Wealth" by A. Cournot (1835), A system of equations of L. Walras General equilibrium theory (1874, 1877), "Mathematical psychology" by F. Edgeworth (1881 ), Marshall's applications of mathematics to economics (1890) and their numerous followers in the twentieth century, especially postwar general equilibrium theories, including Arrow - Debre - McKenzie general equilibrium model (ADM) and The New Macroeconomic Concensus model (NCM), to ensure constant interrelationship and the interaction of these two important fundamental social sciences.

One of the key provisions of the methodology is to determine the relation between theory, model and the real economic world. Most theories are capable of being realized by several models, depending on how each factor is specified. Because theories can be realized by several models, it is usually easier to test a model then a whole theory. If one model fails, the same theory may yield another model that would be more consistent with the data [Perri 6 and C. Bellamy $2012,36]$. Thus, the task of theory and methodology is to justify models that would adequately explain the real economic processes. The requirement that all theories must have economic content causes serious problem in connecting models to data. In general economists work in one of two models: econometrics reduced form models and chosen for more or less ad hoc reasons and fit to data. Theoretical model, in contrast, posit fundamental axioms within a set- up in which agents selfishly maximize utility like in computational agent - based model [Farmer, 2013, 381]. In this regard let us refer to Hausman that economic theory consists of microeconomics, macroeconomics and econometrics. This relationship is brightly shown in DSGE macroeconomic model, which refers to the microfoundations of macroeconomics. DSGE model must be derived from microeconomic theory in an internal and external consistency. As S. Wren-Lewis suggests, it needs a third element, besides internal and external consistency, is intervening: complexity. Complexity, rather than empirical evidence alone, rules out complete or direct internal consistency, and instead internal consistency has to allow an appeal to additional off-model theory. Such modification of microfoundations methodology, to allow off-model justifications for particular relationship, at first sight appears not to compromise the primacy of microeconomic theory over econometric consistency as the criterion for model admissibility [Wren-Lewis 2011, 140-141].

Conclusions. The history of economic thought has proved the uneven development of methodological research. J. St. Mill's works initiated methodological exploration in mid-nineteenth century, which were completed in 1890 during the debate on the "Metodenstreit" method between representatives of the Austrian school of marginal utility and the German historical school. Then there came forty years of a methodological vacuum caused by the World War I, economic crisis and the Great Depression of 1929-1933, when policy rather than methodology became the priority.

The revival of methodological studies begins in the works of F. Knight, T. Hutchison and L. Robbins in 1930s. Results of the methodology study by students of economics and application of mathematics in economics remained contradicting. Thus, in 1992, Frank Hahn due to 
his retirement as a professor of economics at Cambridge University addressed the students choosing a profession with the advice to avoid discussions of mathematics in economics like a plague and therefore give no thought to methodology [Bachhouse 2010, 3]. It should be noted that such statements are still underway, but they rather consider the dominance of mathematics in economics, on the one hand, and the formation of methodological paradigms, methodological discourse that are designed to confirm the status of economics as a science in the system of modern knowledge, on the other. The bimodal methodological discourse proposed in the abstract is aimed at achieving this goal. Principles of philosophy define the subject matter of economics, its epistemological and ontological status based on the principles of demarcation, verification and falsification. Mathematical tools, applying the principle of corroboration, provide economic science with the necessary rigor and precision, mathematical logic and reasonableness of economic axioms and hypotheses.

Thus, the main methodological views on economic theory can, on the one hand, explain the economic life in all its dimensions - the micro - macro - and geo-economic levels, establish certain patterns and trends. On the other hand, using a variety of methods - logical, mathematical, statistical, computer models and programs, new phenomena and processes of local or global nature are explored. That creates conditions for accumulation of empirical and theoretical material that enriches the economic theory, generally shaping the economic science.

\section{References}

1. Blaug, M. (2004). Metodologiya ekonomicheskoj nauki, ili Kak ekonomisty obyasnyayut [The methodology of economic science, or How economists explain]: per. s angl. Moskva. (In Russian).

2. Kirdina, S. (2013). Metodologicheskiy individualizm i metodologicheskiy institucionalizm [Methodological individualism and methodological institutionalism]. Voprosy ekonomikiIssues of economics, 10. (In Russian).

3. Polanyi, K. (2002). Velikaya transformaciya: politicheskie i ekonomicheskie istoki nashego vremeni [The Great Transformation: The Political and Economic Origins of Our Time]: per. s angl. Sankt-Peterburg. (In Russian).

4. Smit, V. (2008).Eksperimentalnaya ekonomika [Experimental economics]: per. s angl. Moskva. (In Russian).

5. Filosofiya nauki: Epistemologiya. Metodologiya. Kultura [Philosophy of Science: Epistemology. Methodology. Culture]: chrestomatiya. (2006). Moskva. P. 368. (In Russian).

6. Frolov, D. (2008). Metodologicheskiy institucionalizm: novyi vzgyad na evolyuciyu ekonomicheskoy nauki [Methodological Institutionalism: A New Perspective on the Evolution of Economic Science]. Voprosy ekonomiki - Issues of economics, 11. (In Russian).

7. Habermas Ju. (1990). Poznanie i interes [Cognition and interest]. Filosofskie nauki, 1, 91. (In Russian).

8. Hausman, D. (1994). Ekonomicheskaya metodologiya v dvuch slovach [Economic methodology in a two words]. Mirovaya ekonomika i mezhdunarodnye otnosheniya, 2. (In Russian).

9. Shchedrovickiy, P. G. (2007). Izmeneniya v myshlenii na rubezhe XXI stoletiya: socio-kulturnye vyzovy [Changes in thinking at the turn of the XXI century: socio-cultural challenges.]. Voprosy filosofii - Problems of philosophy, 7, 39-40. (In Russian).

10. Backhouse R. E. Methodology in: action in Journal of economic methodology, Vol.17, Nr. 1, March, 2010.

11. Baumans M., Davis J. B. Economic methodology. Understanding economic as a science. New York, 2010. 
12. Cohen B. Advanced introduction to international political economy. - Cheltenham, 2014.

13. Dopfer K. Economics in cultural key; complexity and evolution revisited in: The Elgar companion to recent economic methodology / Ed. by Davis J. B., and Hands D. W. - Cheltenham, 2011.

14. Duppe T. How economic methodology became a separate science in: Journal of economic methodology, Vol.18, Nr. 2, June, 2011.

15. Farmer $J$. D. Hypothesis non fingo: problems with the scientific method in economics in: Journal of economic methodology, Vol. 20, Nr. 4, 2013.

16. Friedman M. The methodology of positive economics in: The Methodology of positive economics. Reflections on the Milton Friedman legacy / Ed. by Mäki U. - Cambridge University press, 2009.

17. Hands $D$. $W$. Deweyan pragmatic philosophy and contemporary economic methodology in: Dewey, pragmatism, and economic methodology / Ed. by Khalil E. L. - London and New York, 2004.

18. Herfeld $K$. The world in axioms: an interview with Patrick Suppes in: Journal of economic methodology, Vol. 23, Nr 3, September, 2016.

19. Hoffmann Th. S. Wirtschaftsphilosophie. Ansätze und Perspektiven von der Antike bis heute. - Wiesbaden, 2009.

20. Keizer P. Multidisciplinary economics. A methodological account. - Oxford University press, 2015.

21. Krol Z. Platonism and the development of mathematics. Infinity and geometry. - Warszawa, 2015.

22. Moses J. W., Knutsen T. L. Ways of knowing. Competing methodologies in social and political research. Second edition. - London, 2012.

23. Mulberg J. Social limits to economic theory. - London and New York, 1995.

24. Perry 6 and Ch. Bellamy. Principles of methodology. Research design in social science. Los Angeles, 2012.

25. Robbins $L$. The nature and significance of economic science in: The philosophy of economics. An Antology / Ed. by Hausman D. - Cambridge University press, 2008.

26. Sen $A$. The idea of justice. - London, 2009.

27. The philosophy of economics. An Anthology. Third edition / Ed. by Hausman D. M. - Cambridge University press, 2008.

28. Williamson $O$. Pragmatic methodology; a sketch with applications to transactions cost economics in: Journal of economic methodology, Vol.16, Nr. 2, June, 2009.

29. Wren-Lewis $S$. Internal consistency, price rigidity and the microfoundations of macroeconomics in: Journal of economic methodology, Vol. 18. Nr. 2, June, 2011. 